\title{
PHYTOPLANKTON AS BIOINDICATOR FOR WATER QUALITY IN RELATIONSHIP WITH FISH MORTALITY IN FISH FARMS AT NORTHEAST OF DAMIETTA - EGYPT.
}

\author{
Mohamed A. Deyab \\ Botany Department, Faculty of Science at Damietta, Egypt. \\ (Fax 057.403868)e-mail : maideyab@yahoo.com
}

\begin{abstract}
The phycological and physico - chemical evaluation was performed in three fish farms at northeast of Damietta (Boghdady, Dorgham and Moamen) as well as their irrigation canals over the period from May 2001 to April 2002. The species number was negatively correlated with water salinity and pollution. The data revealed 32, 25 and 28 species number inside the three fish farms Boghdady, Dorgham and Moamin, respectively. Such number increased to become 96,72 and 56 respectively at these canals. Phytoplankton biomass was relatively higher in fish farms than that in irrigation canals. Cyanophyta, Bacillariophyta and Pyrrophyta were mostly the dominant phytoplanktonic groups in the different stations. Phycological indices indicated that water was moderately polluted ( $\beta$-mesosaprobic) in the irrigation canals and heavily polluted (polysaprobic) in the fish farms. There was also low net oxygen production by phytoplankton and high biological oxygen demand in fish farms. The depletion of the dissolved oxygen especially during second half of night in addition to the high concentration of ammonia might lead to fish mortality in subsurface water of fish farms.
\end{abstract}

\section{Introduction}

Human impact on water resources might result in water pollution and could kill healthy life for organisms. The resulting industrialization, urbanization and agricultural runoff have lead to many chemical and physical changes of the aquatic resources (Ormerod et al., 1996). Non -toxic pollutants cause eutrophication (Jenkins et al., 1995). The periodicity and growth of planktonic algae in fish culture pond ecosystems can be related to different physico-chemical factors (EL Otify, 1999). Cairns and Scherier (1962) showed that high concentrations of detergents in organic pollutants completely inhibit the photosynthetic activity in phytoplankton. The high nutrition status of fish farms and the sediment resuspension has a decisive effect on the water quality (Nordvarg and Johansson, 2002). The N and P inputs from animal wastes and outflow of water of these nutrients through fish production, losses through runoff water and the incorporation of these nutrients into the fish pond sediments (Watanabe et al., 2002). 
Although the eutrophic water is characterized by high algal production or growth (Bell, 1991), excessive eutrophication leads to depletion of dissolved oxygen in water that ultimately results in fish death (Goldman and Horne, 1983). Dissolved oxygen is an efficient and sensitive indicator for the water quality conditions and essential for maintaining the fish fertility in fishery bonds (Kollasa, 1988). Generally, each algal species has an optimum oxygen concentration in which it grows well (Schmager, 1986). Biological assessment for water quality is preferable, rapid and accurate and has several advantages over the chemical monitoring in integrating responses to a range of pollutants occurring in water over different time scales (Herman and Adrienne, 1995). Diversity is an important index, which is affected by certain environmental conditions such as water pollution (Steed and Moring 2000). However, Ingrid et al. (1996) suggested that diatom communities and Oscillatoria rubescence, Aphanizomenon flos aqua and Microcystis aeruginosa can be used successfully as bioindicator for water pollution, monitoring eutrophication and assess water quality.

The major objective of the present study is to use phytoplankton as bioindicator for water quality in water systems of three fish farms (Boghdady, Dorgham and Moamin, which depend on animal wastes in their fish feeding and moreover suffer from fish mortality problem mainly during summer) in order to find essential scientific reasons of this problem and consequently to find the practical solution. The performance of such work was conducted through monthly studying the species composition, succession, biomass, productivity, and diversity of phytoplankton in the three fish farms and its irrigation canals.

\section{Material and Methods}

The study area was chosen at the northeast of Damietta. This area, as indicated in figure 1, was represented by Boghdady (on Lake Manzala), Dorgham (on the estuary of River Nile) and Moamin (on Mediterranean Sea).

Some physico - chemical parameters of water were investigated monthly according to Golterman (1969). During June, July and August 2001 (fish mortality months), two determinations were conducted in surface and subsurface water (1m depth) each two hours intervals; the first was the determination of phytoplanktonic primary productivity (as oxygen production) during the light day. The second was the dissolved oxygen over the day and night according to Winkler (1962). Biological oxygen demand (B.O.D.) was monthly determined according to APHA (1989) while sediment analyses were carried out according to Piper (1947) and Jackson (1962). The algal species were identified according to Skuja (1948), Zabelena et al. (1954), Hendy (1964) and Hindak et al. (1975) and counted using an inverted microscope, following sedimentation according to Utermohle (1936). The phytoplankton biomass was calculated according to Edler (1979). The diversity index, saprobic index and compound eutrophication were respectively performed according to Shannon and Weaver (1963), Sladecek (1973) and Round (1981). 


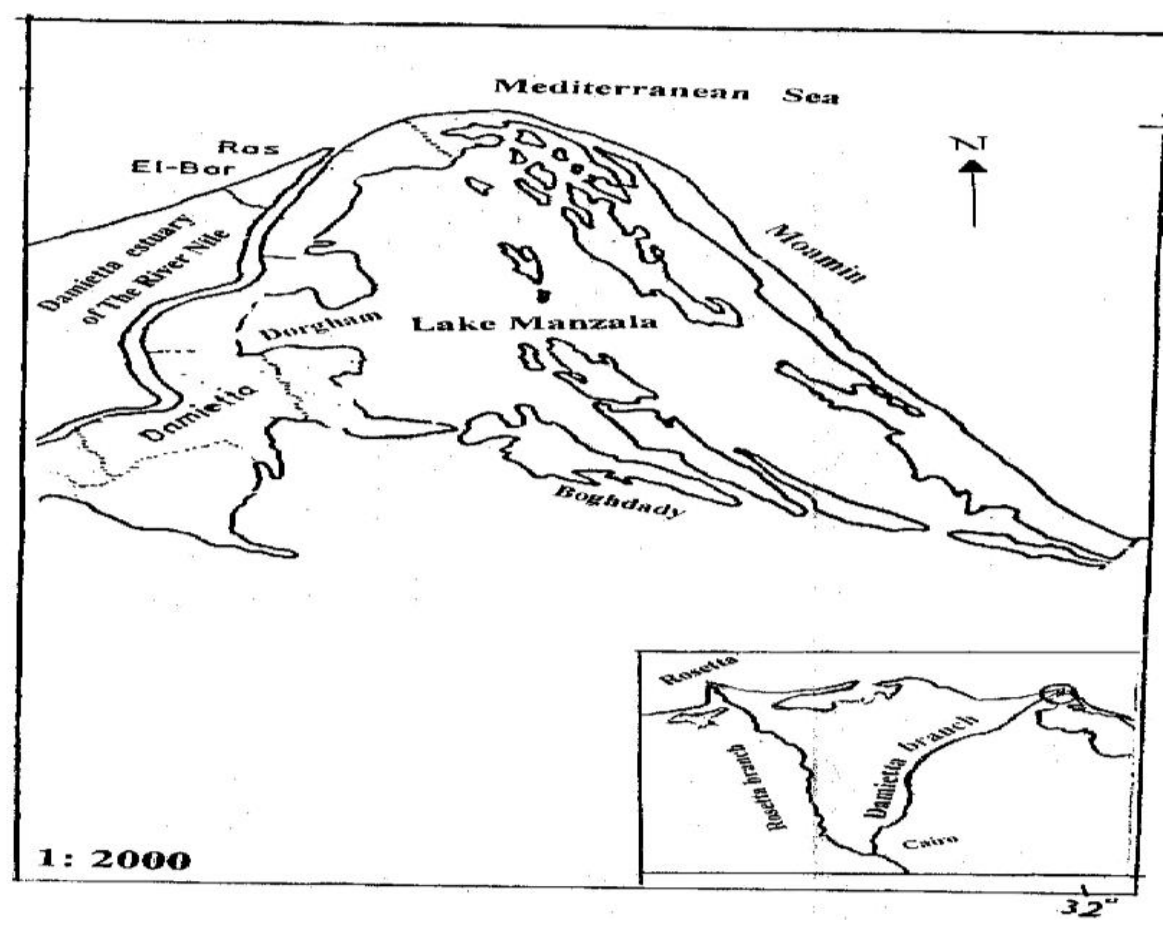

Fig. (1) A map showing the study area.

\section{Results and Discussion}

Phytoplankton and water chemical parameters commonly undergo annual and seasonal cycles (Anderson, 1995). The mean values of water temperature in the study area varied between $20^{\circ} \mathrm{C}$ and $23^{\circ} \mathrm{C}$ (Table 1). These variations of temperature are found to affect the periodicity, diversity and succession of the phytoplankton group (Behrndt, 1990). Means of $\mathrm{pH}$ values of the study area showed more wide range with relative high $\mathrm{pH}$ values during summer months recorded in fish farm. This was concomitant with the peak of phytoplanktonic biomass. These results are in agreement with El-Sabrouti (1990).

Water turbidity showed highly spectral and temporal variations $(\mathrm{p} \leq$ 0.001 ) with very high values at fish farms by increasing organic pollution. The mean values of dissolved oxygen varied between 4.5 to $7.7 \mathrm{mg} / \mathrm{L}$ with local variations. The low values were recorded inside fish farms seemed to be due to using of chicken wastes (organic pollutants) as fish feeds. El-Naggar et al. (1998) reported that organic polluted water is devoid from a measurable concentration of dissolved oxygen. The mean values of biological oxygen demand (B.O.D.) varied between $(8.6$ to $28 \mathrm{mg} / \mathrm{L})$ with high value at fish farms. This was mainly due to high pollution status of water at fish farms. In this connection, Tebbutt (1977) recorded that polluted water is characterized by having B.O.D. of $12 \mathrm{mg} / \mathrm{L}$ or more in average. Variation trends of salinity, electric conductivity, total hardness, 
chloride, T.D.S., Sulphate, Na and K values appeared similar during the study period with high values in fish farm. This may be due to that the highly evaporation rate which would increase salinity of shallow marine and brackish waters in fish farms. Similar observations regarding increased salinity due to the high evaporation rates from shallow water were also reported by Herman and Adrienne (1995).

Table (1) Mean values of some physico-chemical parameters at the three fish farms (F.F.) and their irrigation canals (I.C.) during the period (May 2001 to April 2002).

\begin{tabular}{|c|c|c|c|c|c|c|c|c|}
\hline \multirow{2}{*}{$\begin{array}{l}\text { Stations } \\
\text { Parameters }\end{array}$} & \multicolumn{2}{|c|}{ Boghdady } & \multicolumn{2}{|c|}{ Dorgham } & \multicolumn{2}{|c|}{ Moamin } & \multirow[t]{2}{*}{ F Ratio } & \multirow[t]{2}{*}{ Probability } \\
\hline & I.C & F.F & I.C & F.F & I.C. & F.F. & & \\
\hline Temperature ${ }^{\circ} \mathrm{C}$ & 21.8 & 22.0 & 22.3 & 21.0 & 23.0 & 20.4 & 0.1 & ns \\
\hline $\mathrm{pH}$ & 7.8 & 9.0 & 7.5 & 8.4 & 7.7 & 8.9 & 5.1 & $P<0.01$ \\
\hline Turbidity (NTU) & 5.4 & 9.7 & 4.9 & 18.0 & 5.9 & 17.6 & 12.0 & $\mathrm{p}<0.001$ \\
\hline D. $\mathrm{O}_{2} \quad(\mathrm{mg} / \mathrm{L})$ & 6.4 & 4.5 & 6.8 & 4.8 & 7.7 & 5.6 & 30.9 & $\mathrm{p}<0.001$ \\
\hline B.O.D. mg/L & 11.6 & 28 & 9.8 & 26.2 & 8.6 & 17.8 & 41.2 & $\mathrm{p}<0.001$ \\
\hline Salinity \%0 & 12.8 & 25.3 & 32.8 & 52.8 & 33.7 & 67.1 & 35.4 & $\mathrm{p}<0.001$ \\
\hline Con. $10^{4}$ (m moh) & 1.8 & 3.4 & 4.8 & 6.1 & 4.3 & 8.2 & 28.5 & $\mathrm{p}<0.001$ \\
\hline T. hardness (Meq/L) & 9.3 & 122.7 & 25.4 & 235.5 & 22.9 & 244.8 & 53.4 & $\mathrm{p}<0.001$ \\
\hline $\mathrm{Cl}-1 \quad$ (mg/L) & 0.9 & 3.9 & 11.2 & 14.3 & 11.9 & 24.8 & 9.9 & $\mathrm{p}<0.001$ \\
\hline T.D.S. (g /L) & 3.7 & 31.2 & 41.8 & 63.3 & 56.6 & 76.6 & 31.6 & $\mathrm{p}<0.001$ \\
\hline $\mathrm{SO}_{4}^{--} \times 10^{3}(\mathrm{mg} / \mathrm{L})$ & 3.7 & 3.9 & 3.6 & 4.0 & 3.4 & 3.9 & 13.9 & $\mathrm{p}<0.001$ \\
\hline $\mathrm{Na}_{+}(\mathrm{mg} / \mathrm{L})$ & 19.4 & 75.0 & 30.4 & 94.7 & 25.9 & 87.8 & 16.2 & $\mathrm{p}<0.001$ \\
\hline $\mathrm{K}^{+}(\mathrm{mg} / \mathrm{L})$ & 0.7 & 4.6 & 1.8 & 4.0 & 1.0 & 5.1 & 16.7 & $\mathrm{p}<0.001$ \\
\hline ph.ph.Alk. (Meq/L) & 0.2 & 0.4 & 0.2 & 0.1 & 0.2 & 0.4 & 10.3 & $\mathrm{p}<0.001$ \\
\hline T. alk. (Meq/L) & 3.7 & 4.2 & 2.4 & 2.8 & 5.4 & 6.6 & 14.4 & $\mathrm{p}<0.001$ \\
\hline $\mathrm{NO}_{2}(\mathrm{mg} / \mathrm{L})$ & 0.9 & 2.0 & 0.7 & 1.9 & 1.3 & 2.9 & 3.4 & $\mathrm{p}<0.05$ \\
\hline $\mathrm{NO}_{3}(\mathrm{mg} / \mathrm{L})$ & 0.5 & 3.7 & 0.8 & 1.4 & 0.5 & 2.6 & 5.8 & $\mathrm{p}<0.001$ \\
\hline $\mathrm{NH}_{3} \quad(\mathrm{mg} / \mathrm{L})$ & 2.1 & 4.3 & 1.8 & 3.4 & 2.2 & 2.9 & 1.9 & ns \\
\hline $\mathrm{Si}(\mathrm{mg} / \mathrm{L})$ & 3.1 & 7.8 & 1.2 & 3.7 & 1.6 & 5.1 & 9.6 & $\mathrm{p}<0.001$ \\
\hline $\mathrm{PO}_{4}^{--} \quad(\mathrm{mg} / \mathrm{L})$ & 0.0 & 0.1 & 0.0 & 0.0 & 0.0 & 0.0 & 16.0 & $\mathrm{p}<0.001$ \\
\hline T. $\mathrm{PO}_{4}^{--}$(mg/L) & 146 & 264 & 155 & 322.5 & 192.2 & 361.8 & 13.1 & $\mathrm{p}<0.001$ \\
\hline $\mathrm{Pb}^{++}(\mathrm{mg} / \mathrm{L})$ & 0.9 & 5.9 & 1.5 & 5.1 & 0.9 & 4.1 & 17.4 & $\mathrm{p}<0.001$ \\
\hline $\mathrm{Cu}(\mathrm{mg} / \mathrm{L})$ & 0.0 & 0.3 & 0.0 & 0.2 & 0.0 & 0.2 & 13.9 & $\mathrm{p}<0.001$ \\
\hline $\mathrm{Cd}(\mathrm{mg} / \mathrm{L})$ & 0.1 & 1.1 & 1.1 & 0.8 & 0.3 & 0.2 & 8.0 & $\mathrm{p}<0.001$ \\
\hline Zn (mg/L) & 0.8 & 4.3 & 1.8 & 4.2 & 0.8 & 3.6 & 11.5 & $\mathrm{p}<0.001$ \\
\hline
\end{tabular}

Mean values of ph.ph. alkalinity and total alkalinity showed high variations $(\mathrm{p}<0.001)$ with high values at fish farm. Moss $(1973)$, stated that total alkalinity values greater than $1.4 \mathrm{meq} / \mathrm{l}$ indicated eutrophic conditions. Inorganic - 
$\mathrm{N}$ (nitrite, nitrate and ammonia) was present in excess with higher values in fish farms than in irrigation canals, mainly due to the fish feeding and its metabolites. Moreover, subsurface measuring the $\mathrm{NH}_{3}$ in fish farms water records very high values (ranged from 4.9 to $9 \mathrm{mg} / \mathrm{l}$ ) during summer months (data not shown). In this respect, Reid (1961) found that the concentration of ammonia in the unpolluted water is $\approx 1 \mathrm{mg} / \mathrm{L}$ while in polluted water is $\approx 12 \mathrm{mg} / \mathrm{L}$. In the present investigation, low contents of silica were recorded in irrigation canals, where high growth of diatoms was observed. In fact, Jones et al. (1996) reported that diatoms result in depletion of reactive silica from water. The lower levels of $\mathrm{PO}_{4}$ content detected in the irrigation canals than that in fish farms may be due to the difference of pollution status of water. However, Vollenweider (1971) reported that water with dissolved phosphorus exceed $0.01 \mathrm{mg} / \mathrm{l}$ indicate its eutrophic conditions. There was a high local variation of total soluble phosphorus ( $\mathrm{p}<$ 0.001 ), with high values in shallow water fish farm. This may be attributed to the high degree of pollution (Raymont, 1980). In addition, the table shows that lead, copper, cadmium and zinc have a narrow range of variation. This could be due to run off from agricultural and from sea anti-fouling paints on boats and ships (Kurt et al., 1996).

As shown in figure 2, dissolved oxygen content in surface and subsurface water during 24 hours was lesser in fish farms than in the irrigation canals. The dissolved oxygen in the irrigation canals appeared to be enough for aquatic biota (4.4 - $7.2 \mathrm{mg} / \mathrm{l})$ and nearly, if any, enough in fish farms $(0.7-4.8 \mathrm{mg} / \mathrm{L})$. As a whole, the dissolved oxygen seemed not enough in the subsurface water of fish farms particularly during the second half of night $(2.4-0.7 \mathrm{mg} / \mathrm{L})$. This may be due to the high chemical and biological oxygen demand (C.O.D and B.O.D) from organic polluted water of fish farm. Consequently, fish float at the surface water of fish farm, which has relatively high dissolved oxygen content or may die at subsurface water. It was reported that the minimum concentration of the dissolved oxygen required for healthy growth of fish and all water biota is $5 \mathrm{mg} \mathrm{L}^{-1}$ (Train, 1979). Eutrophication and organic wastes would result in an oxygen deficiency and consequently mass mortality of aquatic organisms (Borum and Sand-Jensen, 1996).

Figure 3 shows the results of phytoplanktonic primary productivity during day light at surface and subsurface water of the fish farms and their irrigation canals. It is clear that oxygen production through phytoplanktonic photosynthesis in fish farms was very low $(-0.3$ to $0.4 \mathrm{mg} / \mathrm{L})$ relative to that recorded in the irrigation canals ( $0.4-1.2 \mathrm{mg} / \mathrm{L})$. On the other hand, there was an inversion in the net oxygen production by phytoplankton at subsurface water of fish farms, a phenomenon that augmented with the progress of day. This inversion was mainly due to the high pollution status of water that would inhibit photosynthetic activity of phytoplankton in addition to the increased oxygen consumption by living biota in the fish farms. 

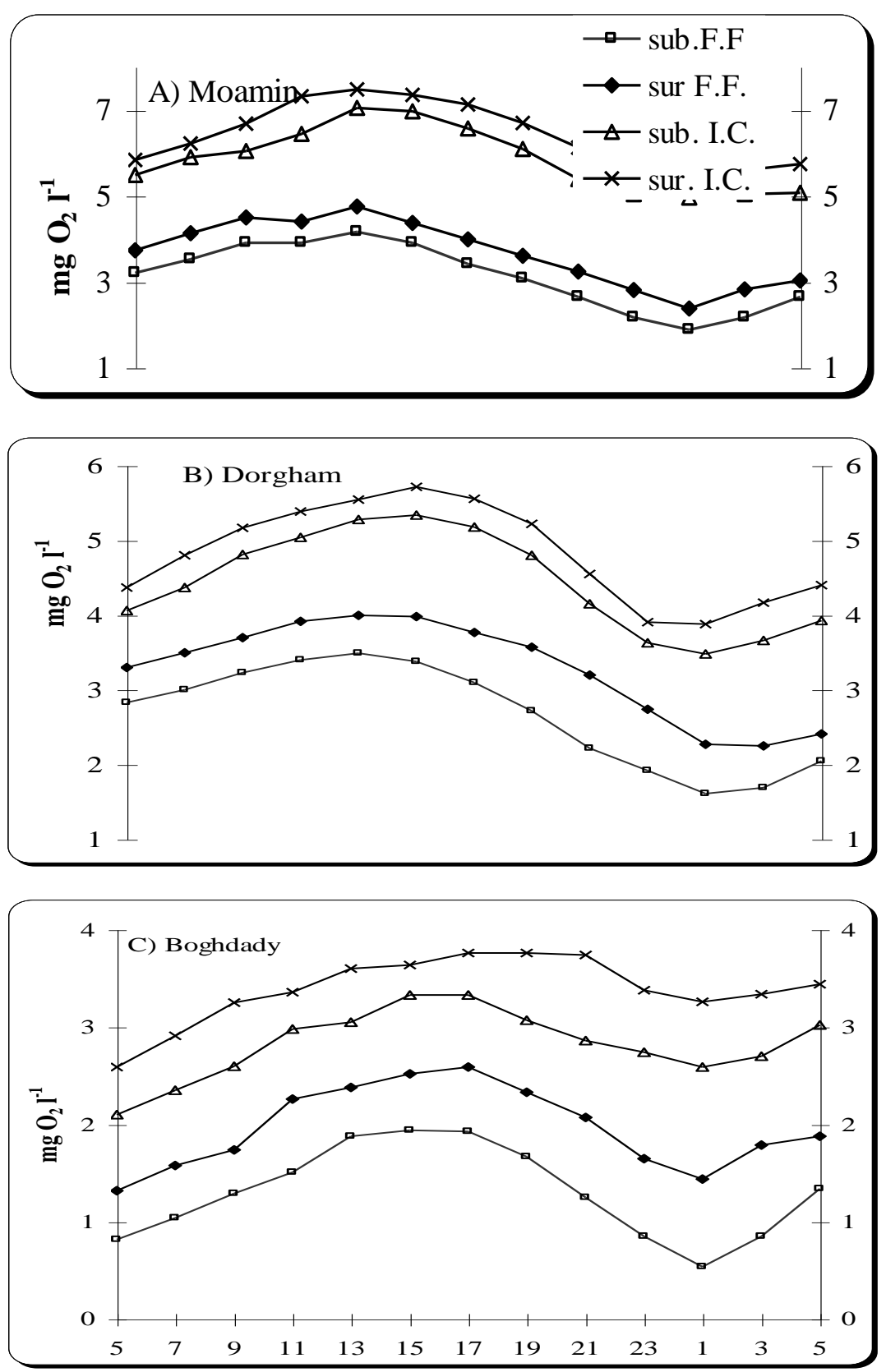

Fig. (2) Mean values of the dissolved oxygen in water during $24 \mathrm{hrs}$ at surface and at (1.0 $\mathrm{m}$ depth) of the three fish farms (F.F.) and its irrigation canals (I.C.). 

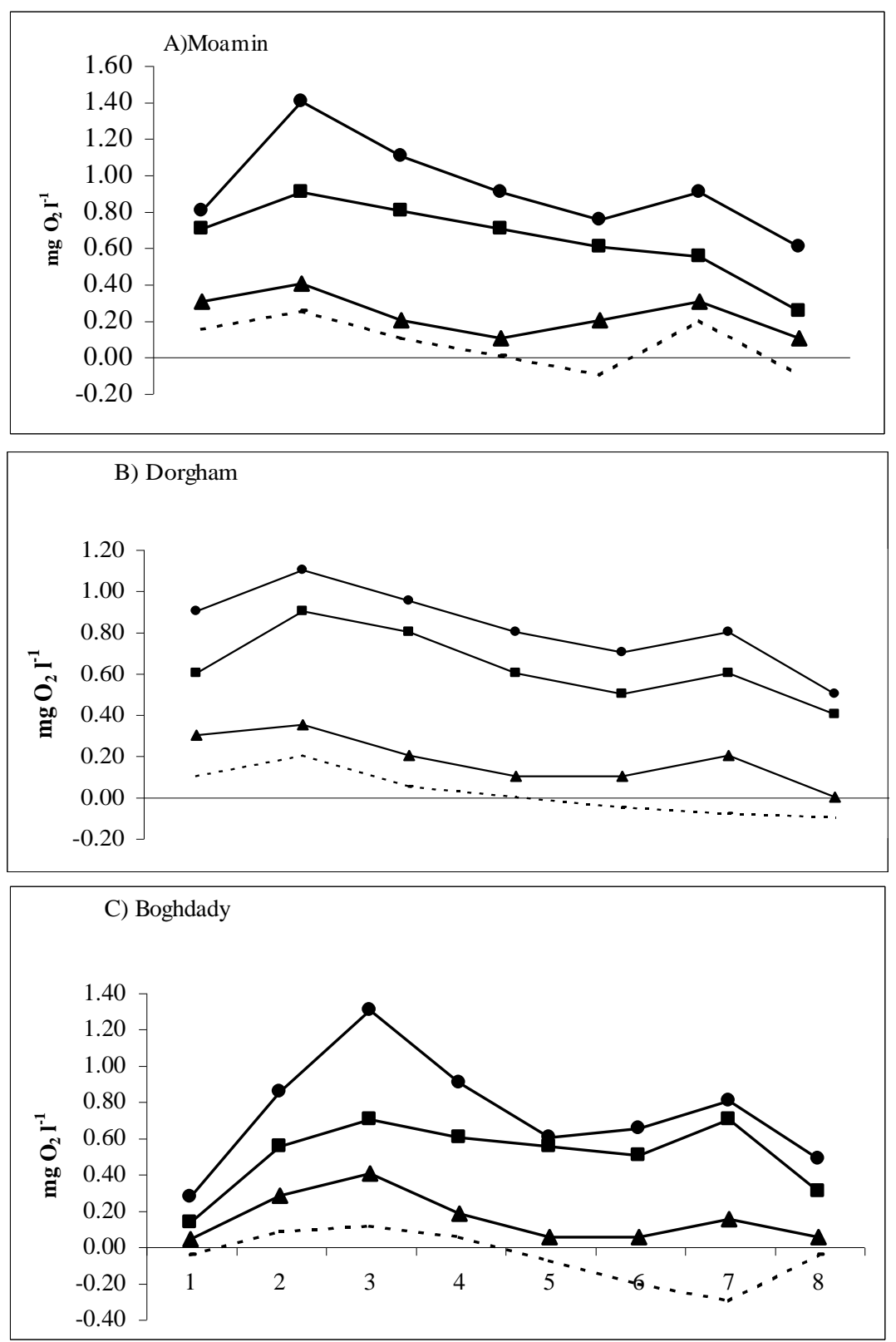

Fig. (3) Mean net phytoplanktonic primary productivity - $\mathrm{mg} \mathrm{O}_{2} / \mathrm{L}$ during light day at surface and at (1.0 $\mathrm{m}$ depth) of the three fish farms (F.F.) and its irrigation canals (I.C.). 


\section{Sediment Analysis}

As revealed in table 2, seasonal variations of $\mathrm{pH}$ values occur in very narrow range (7.4-7.7). On the contrary, there was a wide range of changes in the sedimentary salinity, chlorisity, and electric conductivity values. This could explain the cycles of elements that transfer from sediment to water and vice versa in the saline region. The sedimentary carbonate values were low throughout study the period. In addition, calcium carbonate and sulphate showed the same local variation of salinity because they represent the main part of salt compositions.

Table (2): The mean values of physico-chemical parameters of the sediments in the three fish farms (F.F.) and their irrigation canals (I.C).

\begin{tabular}{|c|c|c|c|c|c|c|c|c|}
\hline \multirow{2}{*}{ Species } & \multicolumn{2}{|c|}{ Boghdady } & \multicolumn{2}{|c|}{ Dorgham } & \multicolumn{2}{|c|}{ Moamin } & \multirow{2}{*}{ 도류 } & \multirow{2}{*}{ 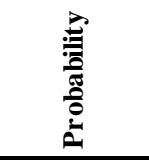 } \\
\hline & F.F & I. C. & F.F & I. C. & F.F & I. C. & & \\
\hline pH & 7.4 & 7.5 & 7.4 & 7.6 & 7.7 & 7.7 & 0.8 & ns \\
\hline Salinity \% & 30.0 & 19.0 & 41.1 & 21.0 & 45.0 & 34.0 & 59.6 & $\mathrm{p}<0.001$ \\
\hline Conductivity m moh & 55.0 & 41.2 & 73.2 & 54.9 & 83.1 & 62.3 & 79.3 & $\mathrm{p}<0.001$ \\
\hline Chloride $\mathrm{mg} / \mathrm{Kg}$ & 11.2 & 8.4 & 8.8 & 6.6 & 12.3 & 9.2 & 1.2 & ns \\
\hline T.hardness mg/kg & 276.0 & 207.0 & 200.0 & 150.0 & 256.0 & 1920 & 51.3 & $\mathrm{p}<0.001$ \\
\hline Carbonate mg/kg & 0.2 & 0.1 & 0.2 & 0.1 & 0.1 & 0.0 & 0.8 & ns \\
\hline Bicarbonate mg/kg & 0.5 & 0.4 & 0.9 & 0.7 & 0.6 & 0.5 & 1.8 & ns \\
\hline Calcium carbonate \% & 85.5 & 76.0 & 87.6 & 85.6 & 84.0 & 76.9 & 2.0 & ns \\
\hline Sulphate $\mathrm{mg} / \mathrm{kg}$ & 0.9 & 0.7 & 0.7 & 0.5 & 0.7 & 0.5 & 1.3 & ns \\
\hline
\end{tabular}

\section{Phytoplankton Distribution}

Phytoplankton studies are much needed for water resources management and to predict the evaluation of aquatic ecosystem (Walater et al., 1996). A total of 119 phytoplankton taxa were recorded in the present study area; the most predominat species are presented in table 3 . The high species number was recorded at the irrigation canals; 96 species at Boghdady (27 Cyanophyta, 41 Bacillariophyta, 11 Chlorophyta, 11 Pyrrophyta and 6 Euglenophyta), 72 species at Dorgham (15 Cyanophyta, 34 Bacillariophyta, 6 Chlorophyta, 12 Pyrrophyta and 5 Euglenophyta) and 56 species at Moamen (16 Cyanophyta, 25 Bacillariophyta, 4 Chlorophyta, 10 Pyrrophyta and 1 Euglenophyta). In contradiction, low species number was recorded inside the three fish farms; 32 species at Boghdady (10 Cyanophyta, 18 Bacillariophyta,3 Pyrrophyta and 1 Euglenophyta), 25 species at Dorgham (8 Cyanophyta, 12 Bacillariophyta, 2 Pyrrophyta and 3 Euglenophyta) and 28 species at Moamen (7 Cyanophyta, 18 Bacillariophyta, 1 Pyrrophyta and 2 Euglenophyta). This may be attributed to 
salinity and pollutions in the fish farms. However, it is known that the number of phytoplankton species decreases with the increase in salinity and pollutions. (Remane and Schliper, 1971).

Cyanophyta, Bacillariophyta and Pyrrophyta are the main algal groups during the period of investigation at all stations. Chlorophyta, and Euglenophyta formed a considerable part of phytoplankton composition. The relative high values of total phytoplankton biomass were recorded at Boghdady followed by Dorgham and Moamin. This was mainly correlated with salinity and trophic status of water. It is reported that the increase in salinity level could cause a reduction in size of algal cell as well as biomass of phytoplankton (Remane and Schliper, 1971). Moreover, Romo and Miracle (1994) reported that there was a relationship between pollution and high population density of phytoplankton.

It is clear from figure 4 that there was a peak of total phytoplankton biomass in fish farms and also in their irrigation canals during months of August, September and October, due to the high growth of Cyanophyta as a result of growth of Anabaena variabilis and Synechocystis salina. Another relative increase in total biomass was also observed during month of April as result of the considerable growth of Bacillariophyta and Pyrrophyta especially Fragillaria intermedia, Nitzschia acicularis, Diatoma vulgare and Nitzschia longissima $v$. parva, Exuivaella compressa, Peridinium trochoideum. In this context, El - Otify (1999) reported that blue - green algae sustained relatively higher percentage compositions of the fish ponds, but dinoflagellates, euglenoid sustained always low percentage composition.

Correlations between the abundance of different phytoplankton groups and environmental variables are shown in figure 5. A high correlation is expressed by relatively long vector roughly pointed into the same direction, whereas arrow pointing into opposite direction indicates low correlation. Thus, Bacillariophyta, Chlorophyta, Cyanophyta and Conjugatophyta were highly correlated with ammonia, nitrite, conductivity and total alkalinity, and were less correlated with nitrate, $\mathrm{pH}$, total phosphorus, chloride, turbidity, ph.ph alkalinity dissolved oxygen, temperature, total hardness $\mathrm{Ba}, \mathrm{Na}, \mathrm{K}$ and $\mathrm{Ca}$. Also, Pyrrophyta was positively correlated with the previous physico- chemical parameters. These situations were mainly due to the eutrophic status of water.

In this study, the phytoplankton indices revealed that the Eutrophication is very high trophic concept of the water body in the three fish farms and moderate trophic concept of their irrigation canals (table 4A). This might be due to that fish farms usually receive organic pollutants (chicken wastes) and inorganic wastes (fertilizers) as fish feedings.

The values of species diversity index in fish farms ranged from 0.48 to 0.9 (table 4B). This may tend to indicate that water of the three fish farms was heavily polluted. On the other hand the relative high value of species diversity in the irrigation canals could suggest that water of these canals were moderately polluted. These predictions are in accordance with $\mathrm{Wu}$ and Suen (1985) who 
concluded that the decrease in community diversity was usually associated with high level of pollutants in the water body. The saprobic quotient signifies water qualities between a moderate pollution $(\alpha-\beta$-mesosaprobic) in the irrigation canals to heavy pollution (polysaprobic) in the three fish farms (table 4C). Indeed, Hellawell (1986) suggested that pollution would greatly affect the phytoplankton growth and diversity.

Table (3): The most predominant species of algal groups at the three fish farms (F.F.) and their irrigation canals (I.C.).

\begin{tabular}{|l|c|c|c|c|c|c|}
\hline \multirow{2}{*}{ Species } & \multirow{2}{*}{ Station } & \multicolumn{2}{c|}{ Boghdady } & \multicolumn{2}{c|}{ Dorgham } & \multicolumn{2}{c|}{ Moamin } \\
\hline & F.F & I.C. & F.F & I.C. & F.F & I.C. \\
\hline Cyanophyta & & & & & & \\
\hline Anabaena flos-aquae (Lyngb.) Breb. & & & & + & \\
\hline Anabaena variabilis & & + & & + & & + \\
\hline Gloeocapsa minuta & & + & & & & \\
\hline Oscillatoria formosa Bory. & + & & + & & + & \\
\hline Pleurochloris polychloris & & & & + & & \\
\hline Synchocystis salina wisl & & + & & + & & + \\
\hline Euglenophyta & & & & & & \\
\hline Euglena caudata Hubner & + & & + & & & \\
\hline Euglena velata Klebs & & & + & & & \\
\hline Euglena proxima Dang. & & & + & & & \\
\hline Dinophyta & & & & & & \\
\hline Exuviaella blatica & & & & + & & + \\
\hline Exuviaella compressa & & & & + & & + \\
\hline Bacillariophyta & & & & & & \\
\hline Cyclotella meneghiniana Kutz. & + & & + & & + & \\
\hline Navicula pygmaea Kutz. & & & + & & & \\
\hline Fragillaria intermedia & & + & & & & \\
\hline Nitzschia acicularis W.Sm. & + & & + & & + & \\
\hline Nitzschia hungarica Grun. & + & & + & & & \\
\hline Nitzschia palea Kutz. & + & & + & & & \\
\hline Nitzschia longissima v. parva & & & & + & & + \\
\hline Nitzschia intermedia Grun. & & & & & & + \\
\hline Navicula distance & & + & & & & \\
\hline
\end{tabular}



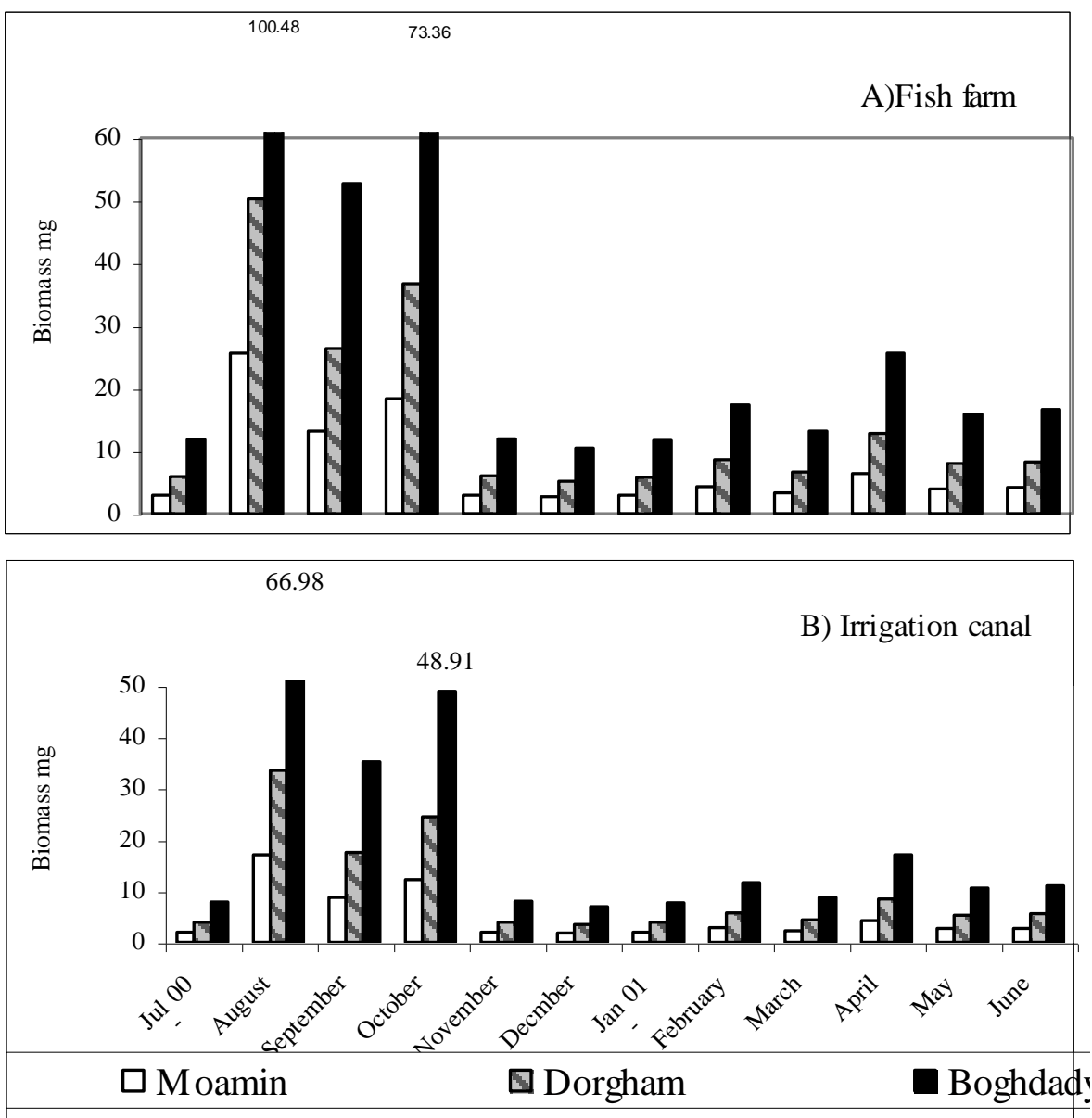

Fig. (4): The total biomass of phytoplankton at the three fish farms and their irrigation canals. 


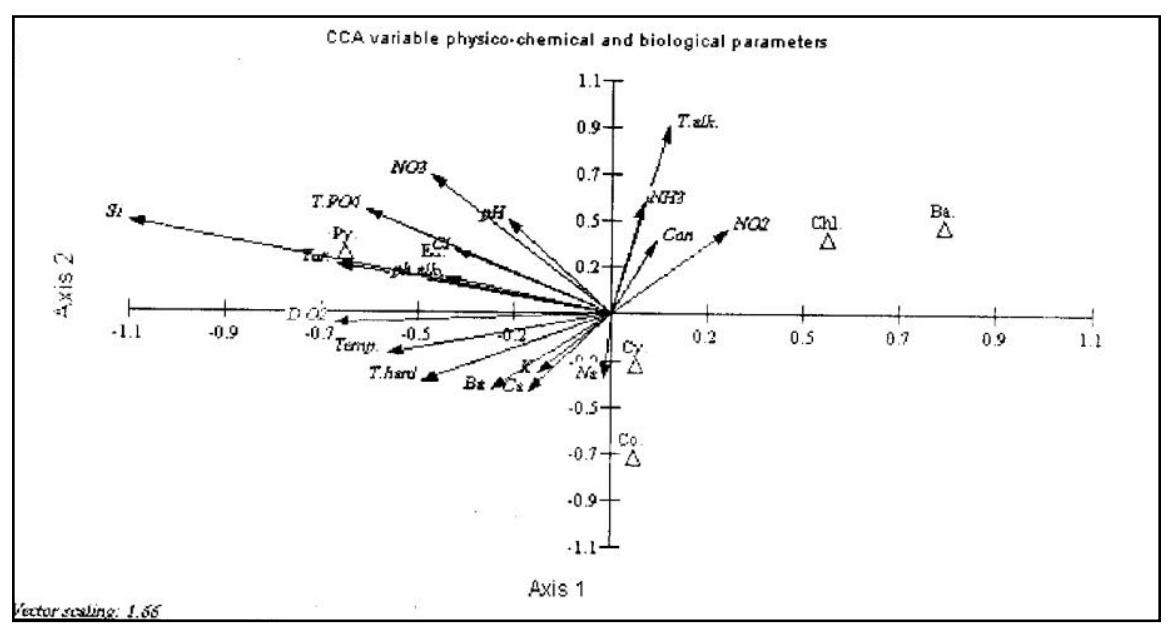

Fig. (5) Canoco analysis plot of Physico-chemical and Biological parameters. $\mathrm{Cy}=$ Cyanophyta, Chl $=$ Chlorophyta, Py $=$ Pyrrophyta, Ba $=$ Bacillariophyta, Co = Conjugatophyta, Eu = Euglenophyta. Temp = Temperature, Sal = Salinity, ph. alk. $=$ ph. ph alkalinity, T.alk. $=$ Total alkalinity, Tur. $=$ Turbidity, T.hard $=$ Total hardness, ${\mathrm{D} . \mathrm{O}_{2}}_{=}$dissolved oxygen, con $=$conductivity. $\mathrm{Si}=$ Silica, $\mathrm{T}$. $\mathrm{PO}_{4}=$ Total phosphorus, $\mathrm{PO}_{4}=$ Orthophosphate.

\section{Conclusion}

The present study indicates that the fish farm water is eutrophic and heavily polluted, a situation that would result in low diversity of phytoplankton. Consequently net dissolved oxygen production decreased in subsurface water of fish farms with a simultaneous increase in biological and chemical oxygen demands especially during the second half of the night. These conditions would subsequently lead to a depletion of dissolved oxygen from subsurface water of fish farms with a decrease in its values from surface water. Moreover, there were very high values of ammonia recorded in subsurface of the fish farms during summer. Such conditions might diminish fish productivity and could enhance fish mortality. Therefore, to conserve the optimal crop in the fish farms for avoidance of fish mortality, fish feeds must be chosen on scientific bases taking into consideration the concomitant importance of daily refreshment of water in the fish farms in order to improve water quality, fish quality and productivity. 
Table (4) Indexes of Eutrophication, Diversity and Saprobity at the three fish farms (F.F.) and their irrigation canals (I.C.).

\begin{tabular}{|c|c|c|c|c|c|c|c|c|c|c|c|c|c|c|}
\hline \multicolumn{2}{|l|}{ Stations } & $\begin{array}{l}\text { May } \\
(2001)\end{array}$ & Jun. & Jul. & Aug. & Sept. & Oct. & Nov. & Dec. & $\begin{array}{l}\text { Jan. } \\
(2002)\end{array}$ & Feb. & Mar. & Apr. & Mean \\
\hline \multicolumn{15}{|c|}{ A- Eutrophication index } \\
\hline \multirow[t]{2}{*}{ Boghdady } & I.C. & 1.2 & 1.2 & 1.4 & 1.3 & 1.6 & 1.6 & 1.5 & 1.6 & 3.2 & 1.2 & 1.2 & 3.2 & 1.7 \\
\hline & F.F. & 3.8 & 3.8 & 3.0 & 3.9 & 3.9 & 4.9 & 3.8 & 4.4 & 4.6 & 4.8 & 3.8 & 4.8 & 4.5 \\
\hline \multirow[t]{2}{*}{ Dorgham } & I.C. & 1.9 & 2.1 & 2.9 & 1.6 & 3.2 & 2.4 & 2.3 & 3.4 & 1.2 & 1.3 & 2.1 & 2.2 & 2.8 \\
\hline & F.F. & 2.9 & 3.1 & 4.5 & 2.9 & 4.8 & 3.5 & 3.4 & 4.6 & 3.8 & 2.0 & 3.2 & 3.8 & 3.8 \\
\hline \multirow[t]{2}{*}{ Moamen } & I.C. & 2.1 & 2.2 & 2.9 & 2.4 & 2.3 & 2.6 & 2.5 & 2.7 & 1.8 & 1.8 & 3.0 & 2.1 & 2.3 \\
\hline & F.F. & 3.2 & 3.2 & 4.4 & 3.5 & 3.5 & 3.9 & 3.8 & 3.1 & 2.7 & 2.7 & 4.5 & 3.2 & 3.6 \\
\hline \multicolumn{15}{|c|}{ B- Diversity index } \\
\hline \multirow[t]{2}{*}{ Boghdady } & I.C. & 1.1 & 1.2 & 1.5 & 1.1 & 1.1 & 1.5 & 1.6 & 1.4 & 0.7 & 0.9 & 1.1 & 1.3 & 1.2 \\
\hline & F.F. & 0.7 & 0.8 & 0.6 & 0.7 & 0.7 & 0.9 & 0.8 & 0.8 & 0.6 & 0.6 & 0.7 & 0.6 & 0.8 \\
\hline \multirow[t]{2}{*}{ Dorgham } & I.C. & 1.4 & 1.1 & 0.9 & 1.5 & 1.9 & 1.1 & 1.3 & 1.4 & 0.99 & 0.9 & 1.2 & 1.0 & 1.2 \\
\hline & F.F. & 0.9 & 0.7 & 0.6 & 0.9 & 0.7 & 0.7 & 0.8 & 0.6 & 0.6 & 0.6 & 0.7 & 0.6 & 0.7 \\
\hline \multirow[t]{2}{*}{ Moamen } & I.C. & 0.9 & 1.6 & 1.4 & 1.0 & 0.7 & 0.9 & 1.5 & 0.9 & 1.1 & 1.3 & 1.5 & 1.4 & 1.2 \\
\hline & F.F. & 0.6 & 0.9 & 0.9 & 0.6 & 0.5 & 0.6 & 0.9 & 0.6 & 0.7 & 0.8 & 0.9 & 0.9 & 0.8 \\
\hline \multicolumn{15}{|c|}{ C- Saprobic index } \\
\hline \multirow[t]{2}{*}{ Boghdady } & I.C. & 1.3 & 1.3 & 1.4 & 1.3 & 1.3 & 1.3 & 0.5 & 1.6 & 3.2 & 1.3 & 1.3 & 3.2 & 1.6 \\
\hline & F.F. & 3.8 & 3.8 & 4.9 & 3.8 & 4.8 & 3.8 & 3.7 & 4.3 & 4.7 & 3.8 & 4.8 & 4.7 & 4.3 \\
\hline \multirow[t]{2}{*}{ Dorgham } & I.C. & 1.9 & 2.1 & 2.9 & 1.3 & 3.2 & 2.3 & 2.0 & 3.2 & 1.3 & 1.4 & 2.2 & 2.3 & 2.2 \\
\hline & \begin{tabular}{|l} 
F.F. \\
\end{tabular} & 2.8 & 3.9 & 4.3 & 3.8 & 4.7 & 3.4 & 3.9 & 4.7 & 1.8 & 2.9 & 3.1 & 3.9 & 3.1 \\
\hline \multirow[t]{2}{*}{ Moamen } & I.C. & 2.2 & 2.2 & 2.9 & 2.3 & 2.3 & 2.6 & 2.3 & 2.1 & 1.8 & 1.8 & 3.1 & 2.2 & 2.3 \\
\hline & $\begin{array}{l}\text { F.F. } \\
\text {. }\end{array}$ & 3.1 & 3.1 & 4.3 & 3.4 & 3.4 & 3.8 & 3.3 & 2.9 & 2.6 & 2.63 & 4.4 & 3.1 & 3.3 \\
\hline
\end{tabular}

\section{References}

American Public Health Association (APHA) (1985): Standard methods for the examination of water and waste water, sewage and industrial wastes. $16^{\text {th }}$ Ed.New York, p.1193.

Anderson NJ (1995): Temporal Scale, phytoplankton ecology and palaeolimnology. Freshwater Biology 34, 367-378.

Behrndt H (1990): The chemical composition of phytoplankton and zooplankton in eutrophic shallow lake. Arch. Hydrobiol. 118(2): 129-145.

Bell PRF (1991): Status of eutrophication in the great barrier reef Lagoon. J. of Marine Pollution Bulletien. 23, 89-93. 
Borum J and Sand-Jensen K (1996): Is total primary production in shallow coastal marine waters stimulated by nitrogen loading? Fresh water - Biological laboratory, Univ. of Copenhangen.

Cairns J and Scherier A (1962): Proc. 17 ${ }^{\text {th }}$ Indust., Waste Conf Purdue Univ, Engin. Extn., Series No. 112, 14-28.

Edler L (1979): Recommendations for marine biological studies in the Baltic Sea. phytoplankton and chlorophyll. UNESCO, Working Group.Baltic Marine Biologists, National Swedish Environmental protection Board, Stockholm.

El-Naggar MEE, Shaaban-Dessouki SA, Abdel-Hamid ML and Aly FA (1998): Studes on the phytoplankton population and physico-chemical coditions of treated sewage discharged in to lake Manzala in Egypt. Microbiol., 21 (2): $183-196$.

El Otify M A (1999): Characteristics of phytoplankton communities in fish culture ponds at Aswan, Egypt. J. Union Arab Biol, Cairo. Vol.7 (B) Botany (Physiology and Algae) 93-116,Nov.99.

El-Sabrouti MA (1990): Texture, chemistry and mineralogy of the bottom sediments of lake Manzalah, Egypt. Bull. Faculty of Science, Alex. Univ. 30(A): $270-294$.

Goldman CR and Horne R (1983): Phytoplankton In Limnology. International student Edition, McGraw Hill International Book Company, London, New Delhi, Paris, Sydney,pp. 197-220.

Golterman HL (1969): Methods for chemical analysis of freshwaters. International biological program by Blackwell Scientific Pub. Oxford and Edinburgh 172pp.

Hellawell JM (1986): Biological indicators of freshwater pollution and environmental management.- Elsevier applied Science Publishers, London, New York: 546p.

Hendy NI (1964): An introductory account of the smaller algae of British Coastal Water. Part v : Bacillariophyceae (Diatoms). London : HMSO.

Herman V.D and Adrienne M (1995): Long-term changes of diatoms and chemistry in head water streams polluted by atmospheric deposition of sulphur and nitrogen compounds. Journal of Fresh water Biology, 34: 579600.

Hindak FM, Komarek J, Marvan P and Ruzicka J (1975): Kluc Na Urcovanic Vytrousnych Rastlin I. Diol. Riasy.4, 630p.

Ingrid J, Helker S and Ormerad S.J. (1996): Diatoms as indicators of river quality in the Nepalese Middle Hills with consideration of the effects of habitat specific sampling. Freshwater 36: 475-486.

Jackson, M. L. (1962): Soil chemical analysis constable and Co. Ltd. London.

Jenkins A, Sloan WT and Cosby BJ(1995): Stream chemistry in the Middle Hills and high mountains of the Himalagas, Nepal. Journal of Hydrology, 166: 61-79. 
Jones RI, Youn and Hartley AM and Bailey A E (1996): Light limitation of phytoplankton development in an obligotrophic lake-loch Ness, Scotland. Freshwater Biology 35: 533-543.

Kollasa J (1988): Investigations on intensifications of carp fingerling production. 5-Physical and chemical properties of water Acta Hydrobiologica 29 (3): 325-337.

Kurt Haglund, Bjorklund M, Gunnare S, Sandberg A, Olander U and Pederson M (1996): New method for toxicity assessment in marine and brackish environment using the macroalga Gracilaria tenuistipitata Hydrobiologia 326/327:317-325.

Moss B (1973): The influence of environmental factors on the distribution of freshwater algae: An experimental study. II- The role of $\mathrm{pH}$ and carbon dioxide .J. Ecol., 61: 157 - 177.

Nordvarg L and Johansson T (2002): The effects of fish farm effluents on the water quality in the Aland archipelago, Baltic Sea. Aquacultural Engineering.25.(4) 253-279.

Ormerod SJ, BaralHS, Brewin PA, Buckton S Ti, Juttner I, Rothfritz H and Suren AM (1996): River habitat surveys and biodiversity in the Nepal Himalaya. Freshwater quality:Defining the indefinable (eds Boon PJ and Howell DL) in press. HM50, Edinburgh.

Piper,C. S. (1947) ): Soil chemical analysis constable and Co. Ltd. London.

Raymont JEG (1980): Plankton and productivity in the oceans. $2^{\text {nd }}$ ed. Vol.1. Phytoplankton, pp. 476.

Reid KG (1961): Ecology of inland waters and estuaries. Textbook, VNR, New York,pp.375.

Remane A and Schliper C (1971): Biology of brackish water in : Elster. HJ Ohle,W (eds) Die Binnengewasser Vol. 25. Sluttgart: E. Schweiizbart' sche Verlagsbuch handlung.

Romo S and Miracle MR(1994): Long -term phytoplankton changes in a shallow hypertrophic lake, Albufera of Valencia (Spain). Hydrobiol., 275/276: 153 - 164.

Round FA (1981): The ecology of algae. Cambridge Univ. Press, Cambridge CB21R, 653P.

Schmager M. (1986): Laboratory studies on the effect of different condition of oxygenation on the bioseston of the upper vistule (Southern Poland) Acta hydrobiologica 28 (314): 329 - 343.

Shannon CE and Weaver W (1963): The mathematical theory of communication. $117 \mathrm{pp}$. University of Illinos Press.

Skuja H (1948): Taxonomic des phytoplanktons einiger seen in uppland, Schweden. Symb.Bot.Upsaliensis.9:1-399.

Sladecek V (1973): Systems of water quality from the biological point of view. Arch Hydrobiol. Bieh. Ergebn. Limnol. 7(I-IV): 1-218. 
Steed JM and Moring PJ (2000): Biodiversity, density compensation and the dynamics of populations and functional groups. Ecology, 81 (2): 361 373.

Tebbutt THY (1977): Principals of water quality control. $3^{\text {rd }}$ ed. Pergamon Press. Robert Maxwell, M.C. Publisher, 201p.

Train RE ( 1979) : Quality criteria for water. Castle House Publication LTD. London, 256p.

Ultermohle H (1936): Quantitative methods Zur untersuchung des Nannoplankon In: Abbrhalden's Handbuck der Biologischen. Arbietsmethoden, 2: 18791937.

Vollenweider RA (1971): Scientific fundamentals of the eutrophication of lakes and flowing waters, with particular reference to nitrogen and phosphorus as factors in eutrophication. - Technical Report DAS/CSI/ 68.27, OECD, Paris. 250P.

Walater K D, Ruth E. H, Erchem A,Evans M, Gudder D, Fritz K and Gray L (1996): The relationship of floods drying, flow and light to primary production and producer biomass in a prairie stream. Hydrobiologia 333: 151-159.

Watanabe T, Long DN, Lan LM, Oanh DTH, Lanh NV, Thanh LN( 2002): Nitrogen and phosphorus balance in fishponds under pig-fish system in the Mekong Delta. JIRCAS Working Report .26, 57-63, 13

Winkler L (1962): Standard method for the examination of water and waste water body. Prin. Co Ing. Albany, N. Y.

Wu JT and Suen Wc (1985): Change of algal associations in relation to water pollution. Bot. Bull. Acad. Sin (Taipei), 26(2), 203-212.

Zabelena, M M, Kucelef EA, Prowkuna, AU, Lafrehko H and Sheshykofa BC (1954): Bacillariophyta identification. Ministry of Education SSSR, Mexico 540p. 


\title{
الهائمات الطحلبية كدليل لجودة المياه وعلاقتها بموت الأسماك في المزارع السمكية بشمال شرق دمياط
}

\author{
محمد علي دياب \\ قسم النبات ـ كلية العلوم بدمياط الجديدة - جامعة المنصورة
}

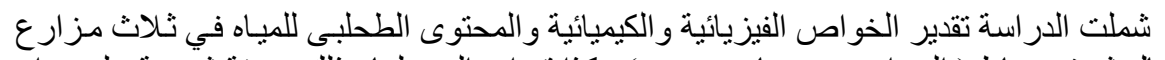

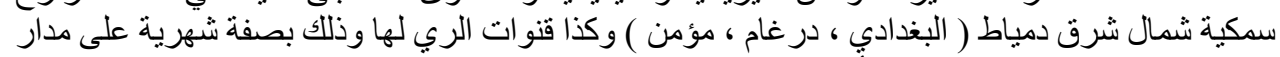

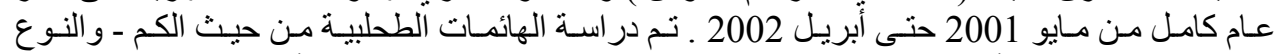

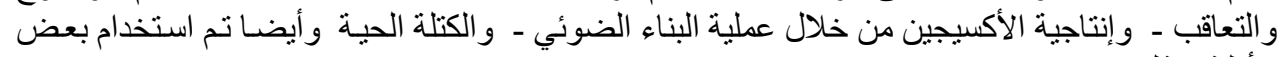
الأدلة مثل:لقياس جودة المياه أو درجة تلوثها في المنطقة قبد البحث ـ كما تم قياس تركيز الأكسجين الذائب في المياه

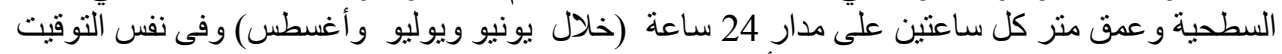

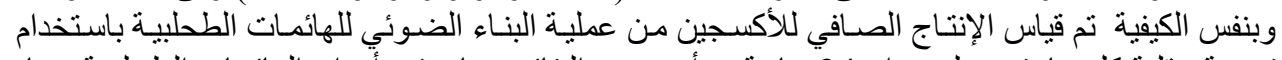

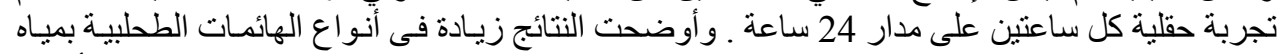

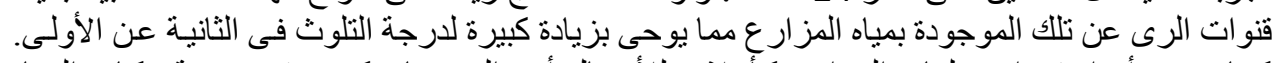

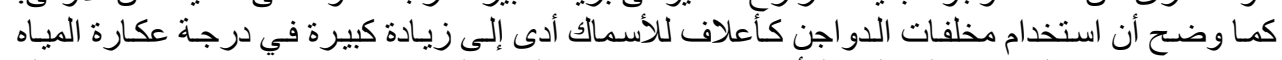

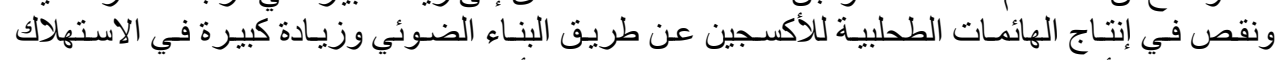

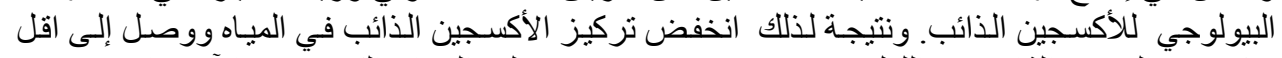

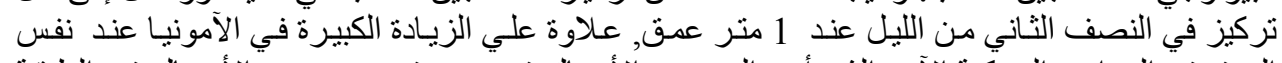

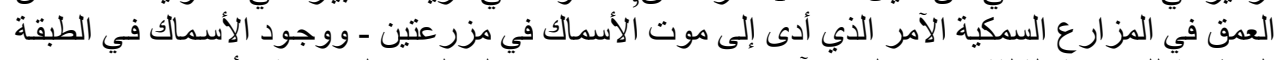

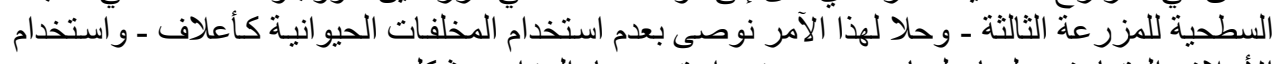

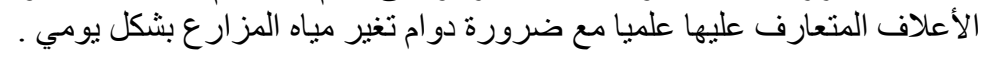

